\title{
Mediterranean Sea
}

5

6 Marta Albo-Puigserver ${ }^{1}$, Sonia Sánchez ${ }^{2}$, Marta Coll $^{1}$, Miguel Bernal ${ }^{3}$, Raquel Sáez-

7 Liante $^{1}$, Joan Navarro ${ }^{1}$, Isabel Palomera ${ }^{1}$

8

9 Institut de Ciències del Mar (ICM-CSIC), 08003 Barcelona, Spain

$10{ }^{2}$ School of Biological Sciences, Monash University, Clayton, Victoria 3800, Australia

$11{ }^{3}$ Centro Oceanográfico de Cádiz, Instituto Español de Oceanografía, 11006 Cádiz,

Spain

13

14 Running Title: Energetic dynamics of sardine and anchovy

15

16

*Corresponding author: albo@icm.csic.es

17 
Abstract

Variability in body condition and energy storage has important implications for fish recruitment and ecosystem structure. Understanding strategies for energy allocation to maintenance, reproduction and growth is essential to evaluate the state of the fish stocks. In this study, we address the energetics dynamics of the annual cycle of anchovies (Engraulis encrasicolus) and sardines (Sardina pilchardus) in the northwestern Mediterranean Sea using indirect and direct condition indices. We assessed and validated the use of morphometric, biochemical and energetic indices for both species. Annual patterns of the relative condition index (Kn), gonadosomatic index (GSI), lipid content (\% lipids) and energy density (ED) were linked to the energy allocation strategy. Our results highlight that anchovy mainly rely on income energy to reproduce, while sardine accumulate the energy during the resting period to be used in the reproduction period. Consequently, variability in the lipid content and ED between seasons was lower in anchovy than in sardine. In both species, we observed an early decline in energy reserves in late summer-early fall, which may be related to unfavourable environmental conditions during spring and summer. Regarding the use of different condition indices, both direct indices, lipid content and ED, were highly correlated with Kn for sardine. ED was better correlated with Kn than lipid content for anchovy. For the first time, a relationship between ED of gonads and GSI for sardine and anchovy was provided, highlighting the importance of the energy invested in reproduction. This work provides new insights into the energy dynamics of sardine and anchovy. We also demonstrate which are the most suitable indices to measure changes in the physiological condition of both species, providing tools for the future monitoring of the populations of these two commercially and ecologically important fish species. 
43 Key-words: anchovy, sardine, capital breeder, income breeder, condition, energy

44 allocation, energy density, lipids.

1. Introduction

Small pelagic fish are a key component of pelagic ecosystems and support important fisheries worldwide (Cury et al., 2000; FAO, 2018). Their significant biomass at midtrophic levels makes these forage fish a main prey for numerous marine predators, thus playing a major role in energy transfer from lower to higher trophic levels (Bakun, 1996; Cury et al., 2011). The two most important small pelagic fish in the Mediterranean Sea, in terms of biomass and commercial interest, are European anchovy (Engraulis encrasicolus, hereafter anchovy) and European pilchard (Sardina pilchardus, hereafter sardine) (Palomera et al., 2007). However, in recent decades, important changes in abundance, landings and biological features (such as growth and body condition) have been reported for both species in the north-western Mediterranean Sea (Brosset et al., 2017; Quattrocchi and Maynou, 2017). These changes have been partially attributed to variations in particular oceanographic parameters and increases in fishing pressure (Brosset et al., 2017; Coll et al., 2019; Saraux et al., 2019; Van Beveren et al., 2014).

Previous studies have highlighted that the decline in body condition of sardine and anchovy observed in the last decade in the Mediterranean Sea may have long-lasting negative effects on their populations (Brosset et al., 2017). Therefore, understanding how these species allocate their energetic resources over the year is fundamental to predict the responses of small pelagic fish to environmental variability and changes, as well as the ultimate effects on marine food webs. These factors hold direct informative value for the management of marine resources and ecosystems. 
Marine organisms have developed several strategies for energy acquisition and allocation to reproduction related to the annual and seasonal fluctuation of the pelagic marine environment. The classical division of these strategies is made between capital and income breeders (Drent and Daan, 1980; Stearns, 1989). In capital breeders, the primary energy source for reproduction comes from reserves stored prior to the spawning season, while in income breeders, reproduction is fully supplied by concurrent energy intake, i.e. current feeding. In practice, life-history strategies are represented along the whole continuum of these two extremes (McBride et al., 2015).

According to previous studies in the Mediterranean Sea, anchovy, which spawns in spring and summer, seems to mainly be an income breeder (Brosset et al., 2015b; Pethybridge et al., 2014; Somarakis, 2005; Somarakis et al., 2004), while sardine, which spawns in fall and winter, seems to mainly be a capital breeder (Ganias, 2009; Ganias et al., 2007; Mustać and Sinovčić, 2009; Pethybridge et al., 2014). In the northwestern Mediterranean Sea, seasonal variability in lipid and energy density has been described in sardine and anchovy with both species presenting higher values in spring and summer (Albo-Puigserver et al., 2017; Brosset et al., 2015a; 2015b; Pethybridge et al., 2014). However, the different breeding strategies lead to a higher energy content and higher seasonal variability in sardine than in anchovy (Albo-Puigserver et al. 2017; Brosset et al., 2015b). Due to their different strategies of energy allocation to growth, reproduction and maintenance, and their opposite reproduction periods, it is plausible to expect that the two species will have different ecological responses to environmental change currently underway in the Mediterranean Sea, such as an increase in sea surface temperature and changes in primary productivity (Giorgi, 2006; Hoegh-Guldberg et al., 2018; Oliver et al., 2018; Piroddi et al., 2017). Yet, it is not well known how these changes affect energy acquisition and allocation in anchovy and sardine populations, 
ultimately affecting their reproduction and growth (Nunes et al., 2011). Brosset et al., (2015b) found a change in the annual peak of sardine's condition in the Gulf of Lions, which shifted from the beginning of autumn between 1971 and1978, to the beginning of summer between 1993 and 2013. The authors hypothesized that this change could be related to a lower quality or quantity of food available in summer (Brosset et al., 2015b). These results highlight the importance of considering the monthly body condition in order to better understand the inter-annual dynamics of these short-lived species.

Individuals in better physiological condition, meaning higher nutritional reserves, may have higher growth and survival rates and greater reproductive success (Brosset et al., 2015b). Therefore, the evaluation of the nutritional and physiological state of a population is increasingly used as an indicator of fish stock state (Brosset et al., 2017; Lloret et al., 2013; Rosa et al., 2010). To evaluate the physiological state of fishes, several condition indices are available (Lloret et al., 2013). Fish condition is a measure of stored energy that can be evaluated with direct condition indices (e.g., energy density and lipid content) or indirect condition indices (e.g., morphometric or organosomatic indices) (Gatti et al., 2018; Lloret et al., 2013; Schloesser and Fabrizio, 2017).

In general terms, lipids are the preferred source of metabolic energy for growth, reproduction, and swimming in fish and the first macro-molecule to be catabolised (Shulman and Love, 1999; Tocher, 2003). On the other hand, proteins and carbohydrates, which are the main compounds of body structure, usually remain rather constant and are less energetic than lipids (Anthony et al., 2000). However, in cases of high lipid depletion, proteins can be mobilised and used as an energy source (Black and Love, 1986). Although the measurement of lipid content has been preferably used in the study of small pelagic fish condition (Rosa et al., 2010; Pethybridge et al., 2014; 
117 Brosset et al., 2015a, 2017), the amount of energy per unit of mass (Energy Density;

118 ED) is the only measure that directly provides information on the average energy of the proximate composition of fish (weighted average of protein, lipid and carbohydrates energy densities; Gatti et al. 2018).

When using condition indices, it is important to understand what the index is measuring and to validate it with other measurements (Gatti et al., 2018; McPherson et al., 2011). The use of lipid content, fatmeter (indirect measure of lipids) and morphometric indices (e.g. relative condition factor; $\mathrm{Kn}$ ), have been recently validated as measures of condition in sardine and anchovy, but there was a week correlation between morphometric indices and lipid content in certain periods of the year (Brosset et al., 2015a). Different studies have proposed that morphometric indices do not only reflect the quantity of reserves, but also changes in proteins (Brosset et al., 2015a; Schloesser and Fabrizio, 2017, Sutton et al., 2000). Therefore, the validation of morphometric indices with a measure of energy density, that integrates an average of the proximate composition, could be more appropriate for certain species. In sardine and anchovy, the use of ED, has never been compared and validated with indirect and direct condition indices in this study area (Albo-Puigserver et al., 2017; Tirelli et al., 2006).

Considering all of the above, the main aims of the present study were (1) to assess seasonal dynamics of the body condition and energy allocation to reproduction in sardine and anchovy in the north-western Mediterranean Sea, and (2) to determine indices and direct condition indices of sardine and anchovy were performed. 
143 Anchovy and sardine samples were

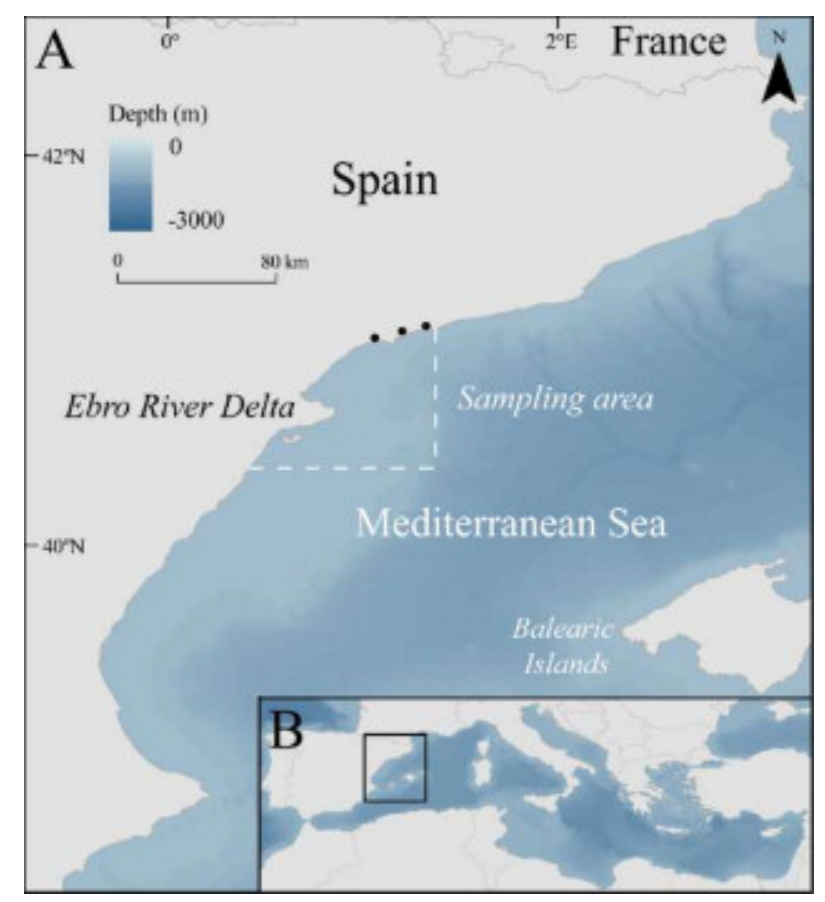

144 collected monthly from purse-seine

145 landings off the Tarragona harbour

146 (Spain; north-western Mediterranean;

147 Fig. 1) which operated in the Ebro

148 Delta continental shelf area from April

1492012 to March 2014. Due to fishing

150 closures, no samples were collected for

151 January 2013 and January 2014. The

Figure 1. Map of the study area where the individuals were collected (A). The sampling area (dashed line) and the fishing harbors where most of the samples were landed are indicated with black circles. Position of the study area in the Mediterranean Basin is also indicated (B).

152 Ebro Delta continental shelf is a major spawning ground for anchovy and sardine

153 (Giannoulaki et al., 2014; Palomera, 1992; Tugores et al., 2011). The primary productivity in this area is largely subjected to the environmental variations of the region. In this area, there is typically a late winter-early spring phytoplankton bloom, enhanced by strong riverine nutrient inputs (Lloret et al., 2004, 2001; Salat, 1996), followed by a spring increase in zooplankton (Sabatés et al., 2007;). Anchovy spawns in warm waters, with temperatures between 17 and $23{ }^{\circ} \mathrm{C}$. These temperatures are found in the waters of the north-western Mediterranean beginning at the end of spring and extending throughout the summer (April - September) (Palomera, 1992; Palomera et al., 2007). Sardine prefers colder waters to spawn, between 12 and $14^{\circ} \mathrm{C}$; therefore, the spawning period of sardine in the north-western Mediterranean is from middle fall until 
the end of winter (November - March; Palomera \& Olivar, 1996; Palomera et al., 2007). All sampled individuals were collected in the harbour, kept in a fridge $\left(4^{\circ} \mathrm{C}\right)$ and dissected in the lab within $24-48 \mathrm{~h}$ after being fished.

\subsection{Condition indices}

A total of 2,078 anchovies and 1,957 sardines were analysed in this study, between 70 and 100 individuals per month were dissected between April 2012 and March 2014 (Table 1). Total body length $(\mathrm{TL}, \pm 0.1 \mathrm{~cm})$, total weight $(\mathrm{TW}, \pm 0.01 \mathrm{~g})$, gutted weight $(\mathrm{GW}, \pm 0.01 \mathrm{~g}), \operatorname{sex}(\mathrm{M}=$ male, $\mathrm{F}=$ female $)$ and gonad weight $\left(\mathrm{W}_{\mathrm{G}} \pm 0.1 \mathrm{mg}\right)$ were recorded for all fish. The macroscopic maturity phase was determined for all individuals using the anchovy and sardine maturity stage keys of (ICES, 2008): $1=$ immature; $2=$ developing; 3 = spawning capable; 4 = spawning; 5 = post-spawning/spent, $6=$ resting.

Only individuals with higher TL than the minimum landing size (TL $\geq 9 \mathrm{~cm}$ for anchovy and TL $\geq 11 \mathrm{~cm}$ for sardine; Ganias et al. 2007) were used in the analysis in order to avoid possible size-related bias due to variation in monthly length frequency distributions of smaller individuals. After dissection, individuals were immediately stored at $-20^{\circ} \mathrm{C}$. Specifically, from all individuals processed in the first year of sampling (from April 2012 to March 2013), 20 per month were entirely frozen for further calorimetric analysis. Then, from other 20 individuals stored per month a piece of muscle was extracted and frozen at $-20^{\circ} \mathrm{C}$ for lipid extraction of muscle and the gonad of these individuals and other individuals dissected but not used for calorimetry analysis, were frozen separately for calorimetric analysis of the gonad (Table 1).

Table 1. Summary of indirect and direct condition indices measured in European sardine and anchovy. For each index the number of samples analyzed (n), the mean total length (TL mean; $\mathrm{cm}$ ) of the individuals and minimum and maximum length 
(min-max; cm) are reported.

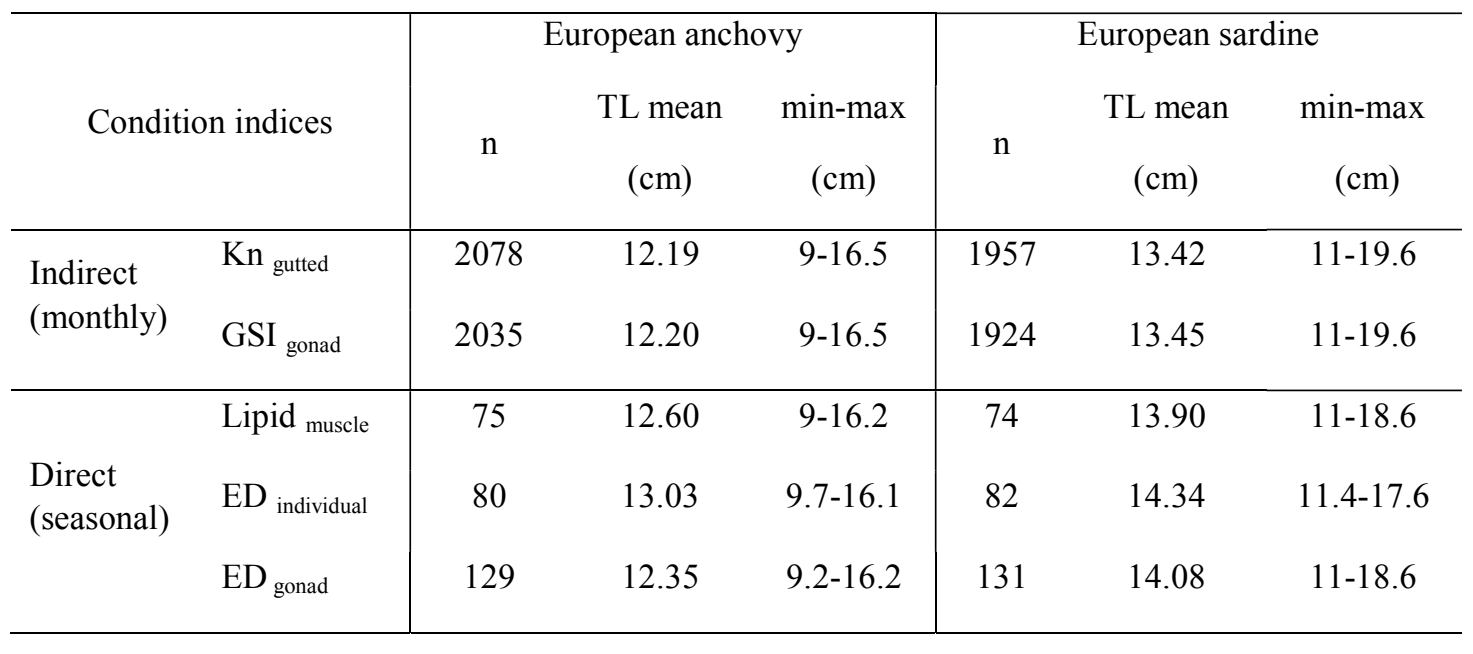

187 The somatic body condition of both species was evaluated by calculating the relative 188 condition factor (Kn, Le Cren 1951). The Kn was obtained as the ratio of the gutted weight $(\mathrm{GW})$ to the corresponding predicted gutted weight $(\mathrm{Wp})$ for a fish of the same length (Le Cren, 1951):

191

(1) $\mathrm{Kn}=\frac{\mathrm{GW}}{\mathrm{W}_{\mathrm{p}}}$

The Wp was obtained by performing a nonlinear regression of $\mathrm{GW}$ as a function of $a \cdot T L^{b}$, where $a$ and $b$ are coefficients estimated from all fish sampled during the years 2012-2014 (with values for anchovies: $a=0.0029, b=3.2538$; and for sardines; $a=$ $0.0037, b=3.2309)$. We used the Kn index as a proxy of somatic condition for fish.

196 Gutted weight is preferred to the total weight to avoid the influence of gonad development on the true somatic condition of individuals (Millán, 1999; Nunes et al., 2011). The Kn was calculated for all individuals sampled of sardine and anchovy (Table $1)$. gonadosomatic index (GSI) and the percentage of reproductively active individuals 
were calculated as a measure of reproduction activity (Basilone et al., 2006; FerrerMaza et al., 2016; Somarakis et al., 2004). GSI was obtained as the ratio of the gonad weight $\left(\mathrm{W}_{\mathrm{G}}\right)$ to the gutted weight $(\mathrm{GW})$ :

(2) $\quad \mathrm{GSI}=\frac{\mathrm{W}_{G}}{\mathrm{GW}} \cdot 100$

The proportion of reproductive individuals during the year was obtained considering actively spawning individuals with maturity stages 3,4 and 5 and those not actively spawning at maturity stages 1,2 and 6 (ICES, 2008).

To relate the Kn and GSI variability with the seasonal environmental changes, monthly satellite-derived sea surface temperatures $\left(\mathrm{SST} ;{ }^{\circ} \mathrm{C}\right)$ and chlorophyll-a concentrations (Chl-a; $\mathrm{mg} \cdot \mathrm{m}^{-3}$, at $2 \mathrm{~km}$ resolution) were obtained for the study area during the sampling period (April 2012 to March 2014) from EMIS (Environmental Marine Information System, https://data.jrc.ec.europa.eu; Melin, 2013).

\subsubsection{Direct body condition indices}

We used biochemical and calorimetry analysis to measure two direct condition indices: lipid content (\% lipids) and energy density (ED). These indices were measured only in individuals that were also used to estimate Kn and GSI. Lipid content was analysed in 75 anchovy individuals and 74 sardine individuals (between 15 and 20 per season, Table 1) from the first year of sampling (spring 2012 to winter 2013). The lipid content of each individual was extracted from a sample of dorsal muscle (200 to $500 \mathrm{mg}$ ) using the Folch method (Folch et al., 1957). The total lipids extracted from each sample were weighed $( \pm 0.0001 \mathrm{~g})$ and were expressed as the percentage of wet weight $\left(\mathrm{W}_{\text {Wet }}, \pm\right.$ $0.0001 \mathrm{~g})$, which was calculated as follows:

\footnotetext{
(3) $\quad \%$ lipids $=\frac{\text { lipids weight }(g)}{\text { sample } W w(g)} \cdot 100$
} 
227 Analyses of the energy density $\left(\mathrm{ED}, \mathrm{kJ} \cdot \mathrm{g}^{-1} \mathrm{~W}_{\mathrm{Wet}}\right)$ were performed on anchovy and sardine specimens from the first year of sampling by direct calorimetry using a Parr 6725 Semimicro Oxygen Bomb Calorimeter (Moline, Illinois, USA). The ED of the entire individual and the ED of gonads were estimated on different individual fish as follows. We used 80 specimens of anchovy and 82 of sardine previously oven-dried (20 per season, Table 1) to estimate the ED of the entire individual using the whole ungutted fish, i.e. including mesenteric fat and gonads. With a different objective, the data on ED of individuals was previously presented aggregated in Albo-Puigserver et al., (2017). ED was determined individually according to the protocol used in previous studies (Albo-Puigserver et al., 2017; Dubreuil and Petitgas, 2009; Tirelli et al., 2006).

The oven-dried individuals were mixed to obtain a homogenised powder of each individual, from which pellets of 150 to $200 \mathrm{mg}$ were obtained with a press. Two of these pellets were used for the determination of the ED, and if the values differed by more than $3 \%$, a third pellet was combusted. The average of the two or three samples was used to estimate the ED of each individual. The ED was converted to a wet-weight basis $\left(\mathrm{kJ} \mathrm{g}^{-1} \mathrm{~W}_{\mathrm{Wet}}\right)$ using the proportion of dry weight $\left(\mathrm{W}_{\text {Dry }}=\mathrm{W}_{\text {Dry }} / \mathrm{W}_{\mathrm{Wet}}\right)$ of each fish. In the case of ED analysis of gonads, if the gonads of an individual fish were not large enough to perform the analysis (the calorimeter can only process samples that range from 25 to $200 \mathrm{mg}$ ), they were pooled by sex, body length and maturity stage to obtain an adequate weight for the analysis (gonad weight: $\mathrm{W}_{\mathrm{G}}$ ). The analysis was determined

247 for 129 anchovies (29 from spring, 33 from summer, 37 from autumn, and 30 from winter) and 131 sardines (45 from spring, 27 from summer, 29 from autumn and 30 from winter). The same protocol described above for the entire individuals was followed for the gonads' ED determination (from an individual or group). 


\subsection{Statistical analyses}

252 Differences in Kn and GSI of anchovy and sardine between months and sexes were statistically compared using PERMANOVA tests (two-way semi-parametric permutation multivariate analyses of variance) based on Euclidean distance matrices with a previous square-root transformation (Anderson et al., 2008). The Spearman's rank non-parametric correlation test between pair of variables was used to examine the relationships between $\mathrm{Kn}$, GSI, sea surface temperature $\left(\mathrm{SST} ;{ }^{\circ} \mathrm{C}\right)$ and chlorophyll-a concentrations (Chl-a; $\mathrm{mg} \cdot \mathrm{m}^{-3}$, at $2 \mathrm{~km}$ resolution) obtained from EMIS (Environmental Marine Information System, https://data.jrc.ec.europa.eu; Melin, 2013).

Differences in lipid content and energy density between seasons, sexes or between maturity stages, in the case of gonad analysis, for sardine and anchovy and between species were also tested using PERMANOVA tests based on Euclidean distance matrices with a previous square-root transformation (Anderson et al., 2008). In the case of significant differences, pairwise tests were performed. Analyses were run using PRIMER-E v6 software (Clarke and Gorley, 2006).

The correlations between the relative condition index $(\mathrm{Kn})$ and the direct condition indexes (\% lipids and ED) were examined using Spearman's rank tests. Relationships between energy density of gonads and the percentage of the gonadosomatic index were explored using logarithmic regressions. Spearman's rank non-parametric correlation tests and linear regression analyses were performed with R v3.3.2. (R Development

271 Core Team, 2018). In all cases, we adopted a significance level of $p<0.05$.

\section{Results}


275 Monthly variation in the GSI values throughout the year showed opposite annual

276 patterns for anchovy and sardine for both sexes (Fig. 2). GSI of anchovy reached the

277 maximum values between April and August while sardine reached maximum values

278 between November and March (Fig. 2B and 2D). Differences between sexes in GSI

279 were observed in both species (anchovy: Pseudo- $\mathrm{F}_{1,1985}=2760.4, \mathrm{p}=0.001$; sardine:

280 Pseudo- $\left.\mathrm{F}_{1,1866}=105.61, \mathrm{p}<0.001\right)$.

281 The percentage of active spawning individuals showed similar patterns to GSI and was

282 related to environmental changes (Fig. 3 and 4). Correlation analysis between

283 environmental variables and GSI showed a positive correlation of anchovy and a

284 negative of sardine with SST and the invers pattern with Chl-a (Fig. 3). Active

285 spawning individuals of anchovy were observed from April, one month after the peak of

286 Chl-a and when SST started to increase, to October, when SST started to decrease (Fig.

$2872 \mathrm{~A}$ and 4). More than $90 \%$ of females were actively spawning in June and July of 2012

288 and in July, August and September of 2013, coinciding with the period of higher SST

289 and lower Chl-a concentrations (Fig. 2A and 4).

290 Sardine actively spawned from October to March, coinciding with the decrease in SST.

291 However, in April and May of 2012, the proportion of active spawning individuals

292 reached almost $50 \%$ and $40 \%$, respectively. The peak of active spawning individuals of

293 sardine was in December and February of 2012 and December 2013 when SST was at

294 its lowest and Chl-a concentration started to increase (Fig. 2A and 4). 


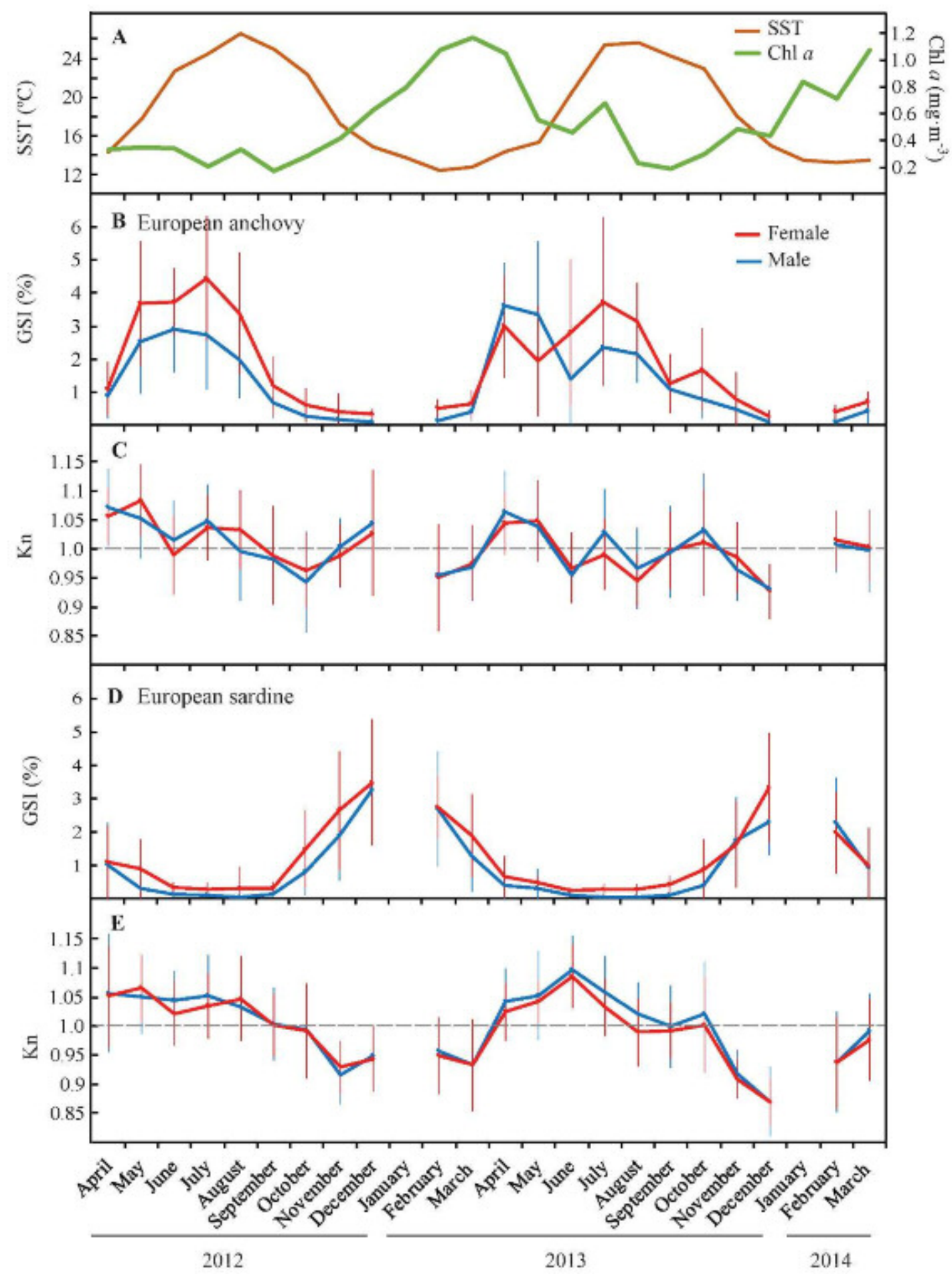

296 Figure 2. Monthly mean sea surface temperature (SST; orange line) and chlorophyll $a$ 297 concentration (Chl- $a$; green line) of the area of study (source: EMIS JRC, 298 https://data.jrc.ec.europa.eu/) (A). Mean and standard deviation of monthly variation of gonadosomatic index (GSI) and relative condition index $(\mathrm{Kn})$ for females (red) and males (blue) of anchovy (B and C) and sardine (D and E), respectively. 


\section{A European anchovy B European sardine}

301

302

303

304

305

306

307

308

309

310

311

312

313

314

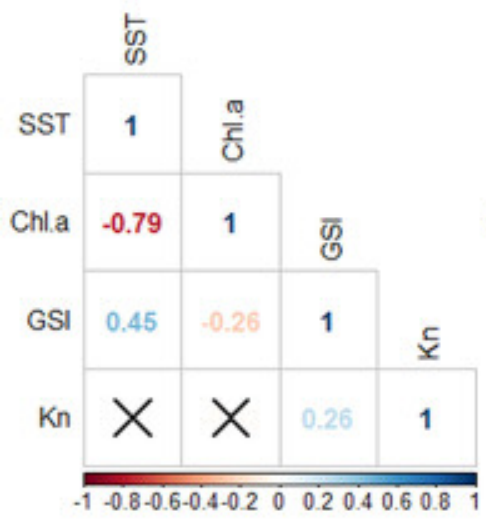

Figure 3. Spearman correlation matrix of the monthly indirect condition indices; relative condition index $(\mathrm{Kn})$ and gonadosomatic index (GSI), with environmental variables; sea surface temperature (SST) and chlorophyll-a concentrations (Chl.a) for anchovy (A) and Sardine (B). 'X' represents non-significant correlation parameters according to a $0.05 \mathrm{p}$-value significant level. The colour gradient from dark red to dark blue correspond to negative to positive correlation strength, respectively.

The Kn of anchovy exhibited high intra-annual and even intra-seasonal variability and was synchronous between sexes (Fig. 2C). The correlation between anchovy Kn and environmental variables was not significant (Fig.3A). There were significant differences in $\mathrm{Kn}$ between months (Pseudo- $\mathrm{F}_{21,1999}=27.56, \mathrm{p}=0.001$ ), but not between sexes (Pseudo- $\left.\mathrm{F}_{1,1999}=0.18, \mathrm{p}=0.67\right)$. High values of $\mathrm{Kn}$ were observed in spring and low values in fall. Kn and GSI values exhibited a weak but significant positive correlation $\left(r_{s}=0.26, p<0.001 ;\right.$ Fig. 3A) 
A

European anchovy

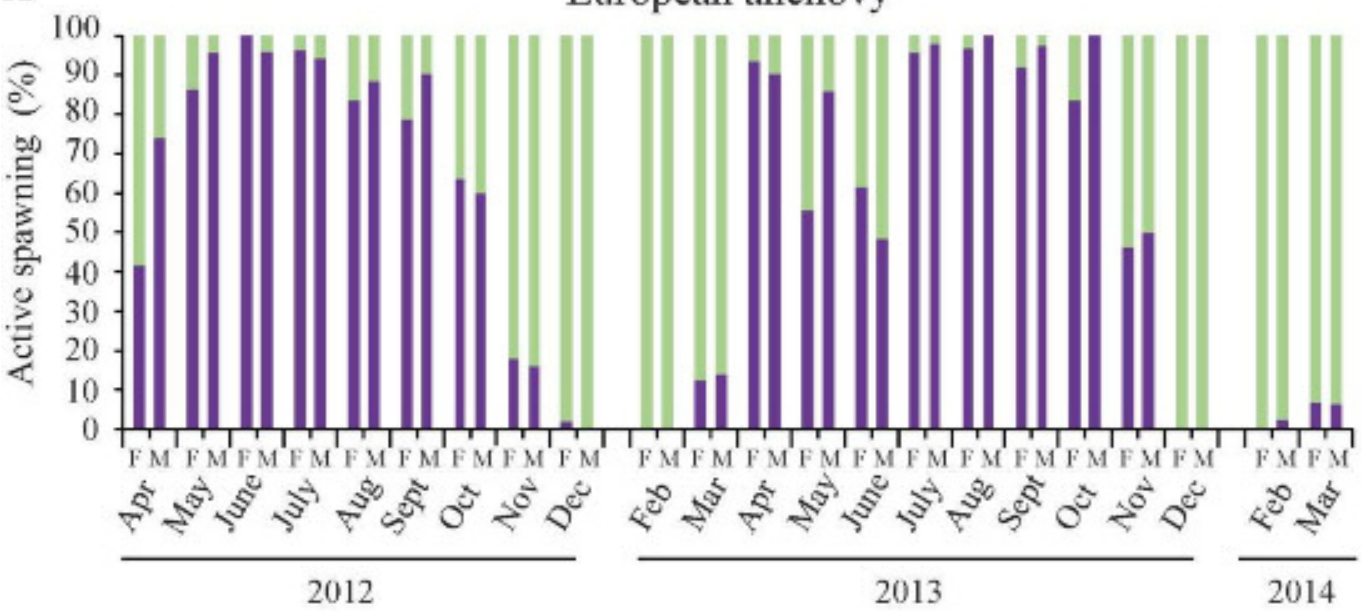

B

European sardine

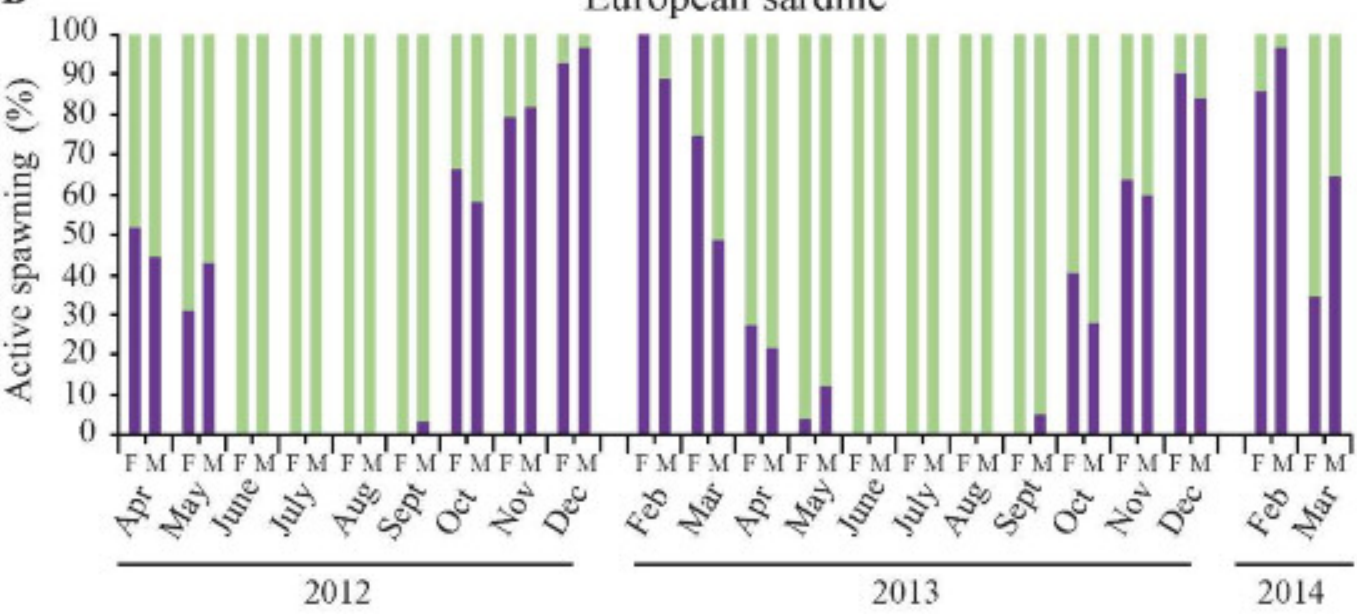

316 Figure 4. Monthly variation of the percentage of mature active individuals in blue

317 (maturity stage 3, 4 and 5) and immature and resting individuals in green (maturity

318 stage 1, 2 and 6) for anchovy (A) and sardine (B). Females (F) and males (M)

319 proportions are represented separately. Maturity stages were classified following ICES

320 (2008).

321 For sardine, significant differences in Kn between months and sexes were observed

322 (Pseudo- $\mathrm{F}_{21,1877}=67.45, \mathrm{p}=0.001$; Pseudo- $\mathrm{F}_{1,1877}=5.77, \mathrm{p}=0.02$, respectively) (Fig. 2E).

323 However, the differences between sexes were only observed in August 2013 (pairwise

324 comparison $t=2.36, p=0.02$ ). Individuals had higher $K n$ values during spring and

325 summer and lower values during fall and winter and positive correlation between SST

326 and Kn were found (Fig. 2D, E, 3B). Kn and GSI exhibited a significant negative

327 correlation $\left(\mathrm{r}_{\mathrm{s}}=0.44, \mathrm{p}<0.001\right)$. 


\subsection{Variation in the direct condition indices}

329 In both species, significant seasonal variations in lipid content were observed (Pseudo$330 \mathrm{~F}_{3,71}=20.33, \mathrm{p}=0.0001 ;$ Pseudo- $\mathrm{F}_{3,70}=19.15, \mathrm{p}=0.0001$, for anchovy and sardine, 331 respectively). In the case of anchovy, only spring had significantly higher lipid content

332 (Fig. 5A). Regarding sardine, lipid content in spring and summer was similar and significantly higher than in fall and winter (Fig. 5B). Lipid fraction in the muscle of anchovy and sardine was similar between sexes (Pseudo- $\mathrm{F}_{1,73}=3.69, \mathrm{p}=0.05$; Pseudo$\mathrm{F}_{1,72}=1.44, \mathrm{p}=0.24$, for anchovy and sardine, respectively).

Similar to lipid content, in both species differences in ED were only found between seasons (Pseudo- $\mathrm{F}_{3,71}=8.55, \mathrm{p}=0.0001$ for anchovy and Pseudo- $\mathrm{F}_{1,73}=21.21, \mathrm{p}=0.0001$ for sardine) and not between sexes (Pseudo- $\mathrm{F}_{2,71}=0.35, \mathrm{p}=0.67$ for anchovy and Pseudo$\mathrm{F}_{1,73}=1.94, \mathrm{p}=0.14$ for sardine). In the case of anchovy, the pairwise comparison of ED between seasons showed that ED was at a maximum in spring and declined in summer and fall with significantly different ED values, while in winter the ED of anchovy was similar to the ED levels of summer (Fig. 5C). For sardine, in spring and summer on the one hand and in fall and winter on the other hand the individuals had similar ED values. Between the two periods (spring-summer and fall-winter) significant differences were found in ED, similar to that observed for lipid content (Fig. 5D).

Comparing the two species, the lipid content of sardine in spring, summer and winter was significantly higher than in anchovy (Pseudo- $\left.\mathrm{F}_{1,141}=64.98, \mathrm{p}=0.0001\right)$, and no differences in the lipid content was observed in fall between the two species (Figs. 5A and 5B). Similarly, in the case of ED, sardine values were significantly higher in spring, summer and fall than in anchovy (Pseudo- $\left.\mathrm{F}_{1,154}=35.18, \mathrm{p}=0.0001\right)$, and no differences in 


\section{European anchovy European sardine}

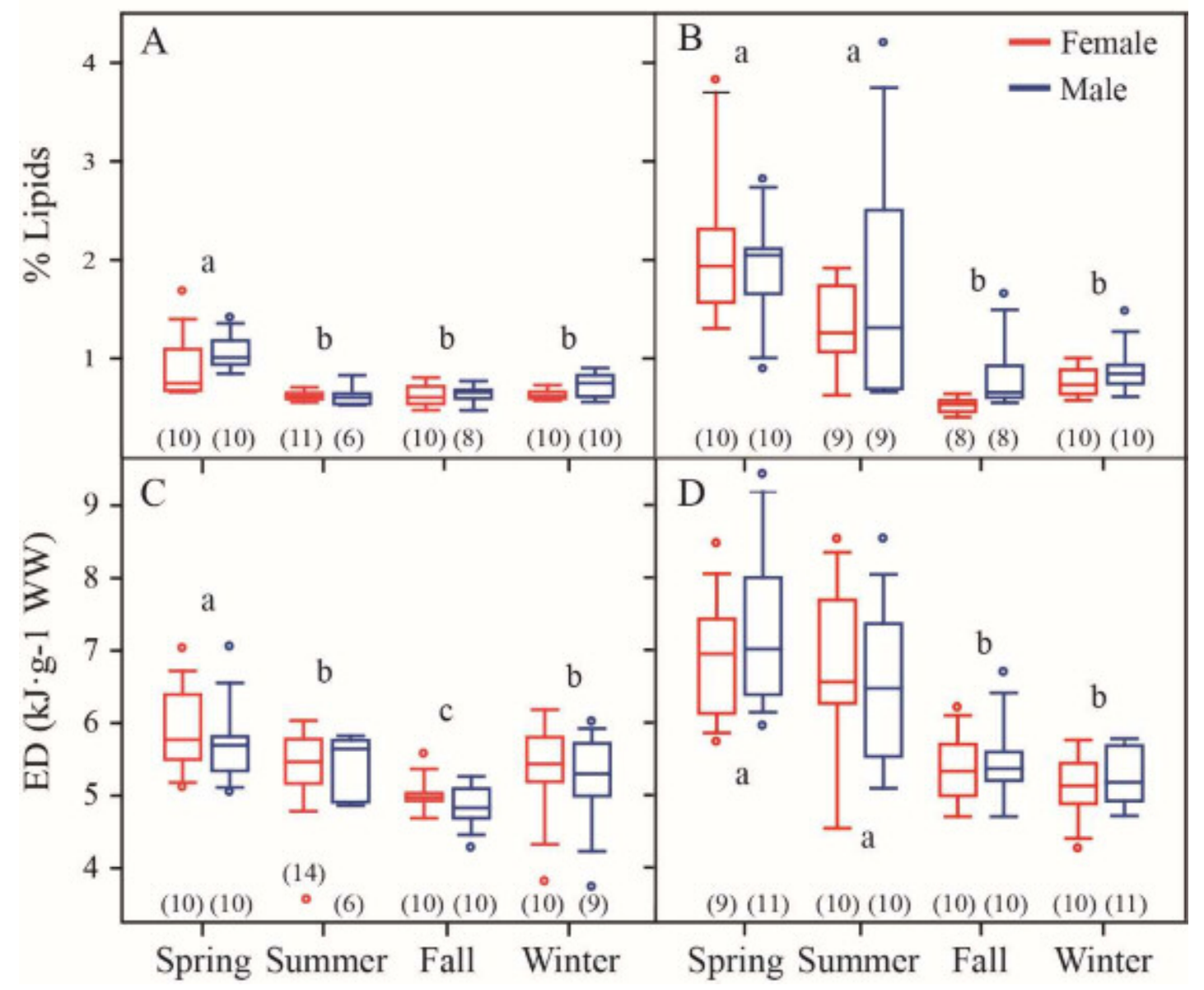

353 Figure 5. Boxplots of seasonal lipid content (A-B) ( $\%$ lipids $\cdot \mathrm{g}^{-1}$ wet weight) and energy 354 density (C-D) $\left(\mathrm{kJ} \cdot \mathrm{g}^{-1}\right.$ wet weight) of anchovy and sardine. Female and males individuals 355 are indicated in red and males, respectively. Box length represent interquartile range, 356 bar length represent range and horizontal lines represent median values, dots are 357 outliers. Number in brackets are the sample size of each boxplot. Pairs of means differing significantly $(\mathrm{P}<0.05)$ by pairwise test between seasons within each graph and both sexes together are indicated by letters- seasons with the same letter were not significantly different.

In the case of the direct index related to reproduction activity, the calorimetry of gonads, anchovy and sardine had similar ED values in gonads $\left(\right.$ Pseudo- $\mathrm{F}_{1,210}=1.95, \mathrm{p}=0.16$,

363 Figure 6). For both species, energy density of gonads varied between reproduction stages, with higher values of $\mathrm{ED}_{\text {gonads }}$ in actively spawning individuals (reproduction 
366 (Pseudo- $F_{5,210}=49.18, p=0.0001$; Table 2, Figure 6). No significant differences were

367 detected between sexes in the $\mathrm{ED}_{\text {gonads }}$ of anchovy (Pseudo- $\mathrm{F}_{1,101}=7.29, \mathrm{p}=0.79$ ), while

368 sardine did present differences in $\mathrm{ED}_{\text {gonads }}$ between sexes (Pseudo- $\mathrm{F}_{1,109}=15.07$, $369 \mathrm{p}=0.0005)$.

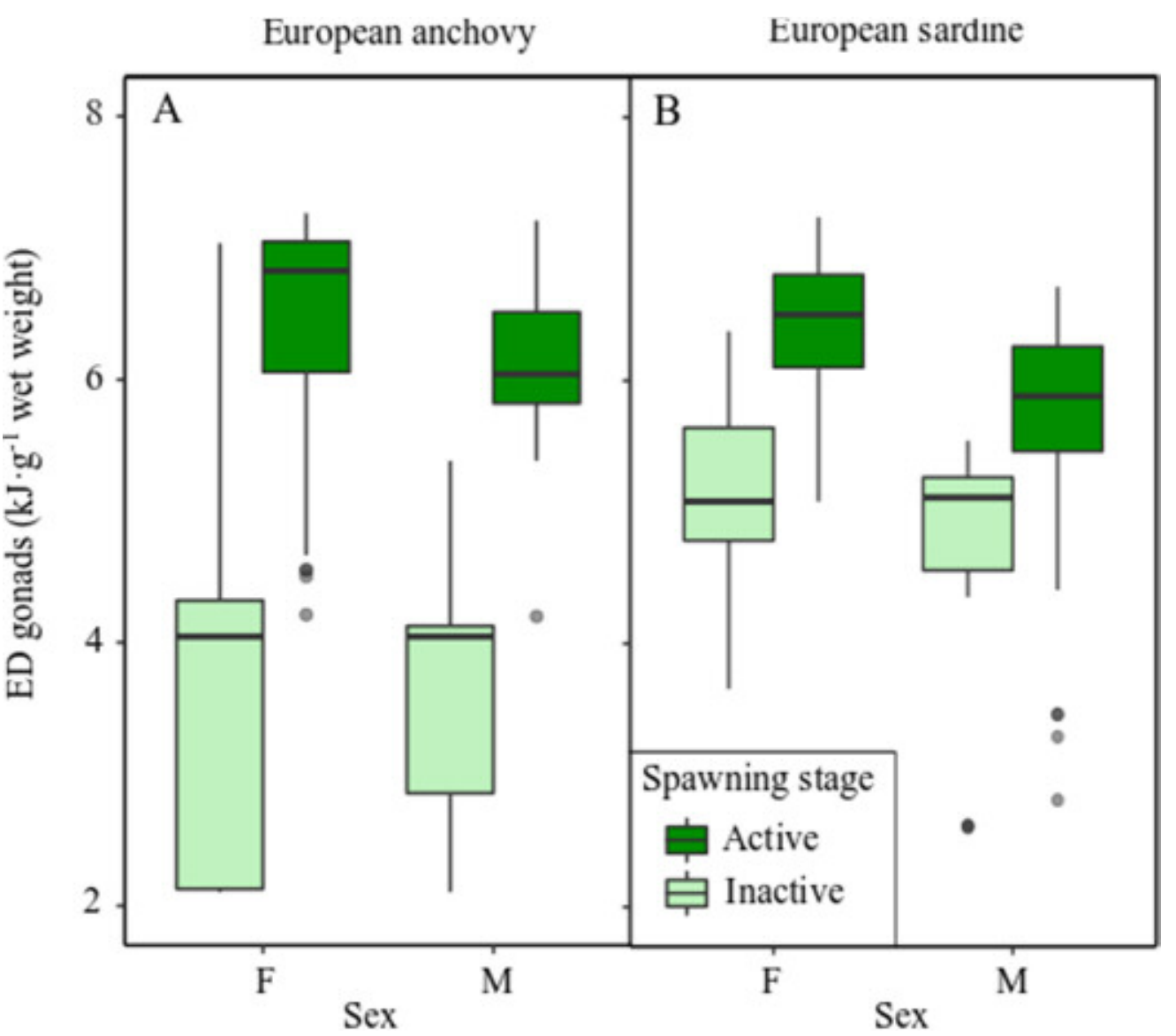

371 Figure 6. Boxplot of Energy Density (ED; $\mathrm{kJ} \mathrm{g}^{-1}$ of wet weight) measured in gonads of active spawning individuals (reproduction stage 3, 4 and 5) and inactive individuals including immature and resting individuals (reproduction stage 1,2 and 6) for females (F) and males (M) of European anchovy (A) and sardine (B). 
Table 2. Mean and standard deviation of Energy Density of gonads (ED; $\mathrm{kJ} \mathrm{g}^{-1}$ of wet weight) and number of individuals analyzed (n) of anchovy and sardine. Cells with no data are indicated (nd).

\begin{tabular}{|c|c|c|c|c|c|}
\hline \multirow{2}{*}{$\begin{array}{c}\text { Maturity } \\
\text { stage }\end{array}$} & \multirow[b]{2}{*}{ Sex } & \multicolumn{2}{|c|}{ European anchovy } & \multicolumn{2}{|c|}{ European sardine } \\
\hline & & $\mathrm{n}$ & $\begin{array}{c}\text { ED gonad } \\
\left(\mathrm{kJ} \cdot \mathrm{g}^{-1} \mathrm{WW}\right)\end{array}$ & $\mathrm{n}$ & $\begin{array}{c}\text { ED gonad } \\
\left(\mathrm{kJ} \cdot \mathrm{g}^{-1} \mathrm{WW}\right)\end{array}$ \\
\hline \multirow{2}{*}{1} & $\mathrm{~F}$ & 8 & $3.14 \pm 1.12$ & 11 & $4.48 \pm 0.24$ \\
\hline & M & 10 & $3.51 \pm 1.26$ & & nd \\
\hline \multirow{2}{*}{2} & $\mathrm{~F}$ & 4 & $5.32 \pm 1.28$ & 2 & $5.84 \pm 0.22$ \\
\hline & M & 3 & $4.81 \pm 0.69$ & 6 & $3.88 \pm 1.63$ \\
\hline \multirow{2}{*}{3} & $\mathrm{~F}$ & 24 & $6.77 \pm 0.66$ & 22 & $6.71 \pm 0.23$ \\
\hline & M & 16 & $6.02 \pm 0.54$ & 12 & $5.79 \pm 0.84$ \\
\hline \multirow{2}{*}{4} & $\mathrm{~F}$ & & nd & 1 & 6.53 \\
\hline & M & 1 & 7.21 & 4 & $6.09 \pm 0.72$ \\
\hline \multirow{2}{*}{5} & $\mathrm{~F}$ & 11 & $5.52 \pm 1.07$ & 17 & $5.86 \pm 0.48$ \\
\hline & M & 6 & $5.92 \pm 0.89$ & 8 & $5.11 \pm 1.13$ \\
\hline \multirow{2}{*}{6} & $\mathrm{~F}$ & 17 & $3.56 \pm 1.06$ & 20 & $5.23 \pm 0.81$ \\
\hline & $\mathrm{M}$ & 12 & $3.52 \pm 0.74$ & 17 & $4.99 \pm 0.63$ \\
\hline
\end{tabular}

383 The relationships between the indirect condition index $\mathrm{Kn}$ and the two direct indices,

384 ED and \% lipid, were positively correlated for anchovy and sardine (Fig. 7). For

385 anchovy, the correlation was stronger between Kn and ED (Fig. 7A) than in the

386 correlation between Kn and \% lipid (Fig 7C). For sardine, the higher correlation was

387 between Kn and \% lipid (Fig. 7D) followed by ED (Fig. 7B). 


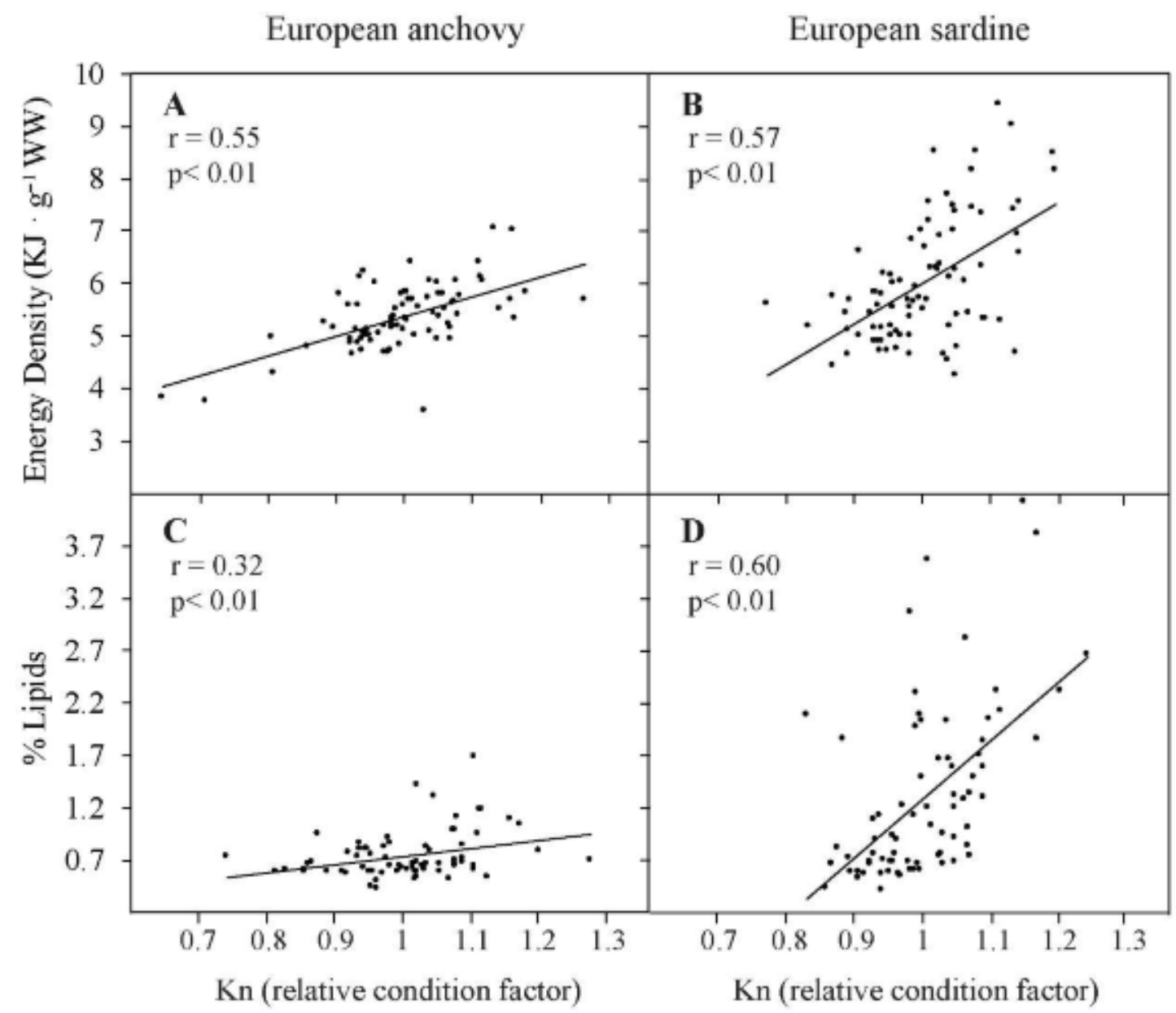

389 Figure 7. Relationships between the relative condition factor $\left(K_{n}\right)$ and energy density 390 (ED; $\mathrm{KJg}^{-1}$ wet weight) and lipid content (\% Lipids) for anchovy (A, C) and sardine (B, 391 D), respectively. Spearman correlation and the level of significance are indicated (r; p). 392 Lines indicate significant correlations.

393 When comparing direct and indirect indices of the energy invested in reproduction, $\mathrm{ED}_{\text {gonads }}$ of anchovy and the GSI showed a strong positive correlation for both sexes $\left(r_{s}=0.85, p<0.001 ; r_{s}=0.80, p<0.001\right.$, for females and males, respectively). The relationship fitted to a logarithmic regression explained $69 \%$ and $62 \%$ of the variance in

397 anchovy females and males, respectively (Fig. 8A). Sardine also showed a positive correlation between $\mathrm{ED}_{\text {gonads }}$ of females and males and GSI $\left(\mathrm{r}_{\mathrm{s}}=0.86, \mathrm{p}<0.001 ; \mathrm{r}_{\mathrm{s}}=0.64\right.$, $\mathrm{p}<0.001$, for females and males, respectively). The logarithmic regression of sardine 
401 females explained $72 \%$ of the variance (Fig. 8 B).

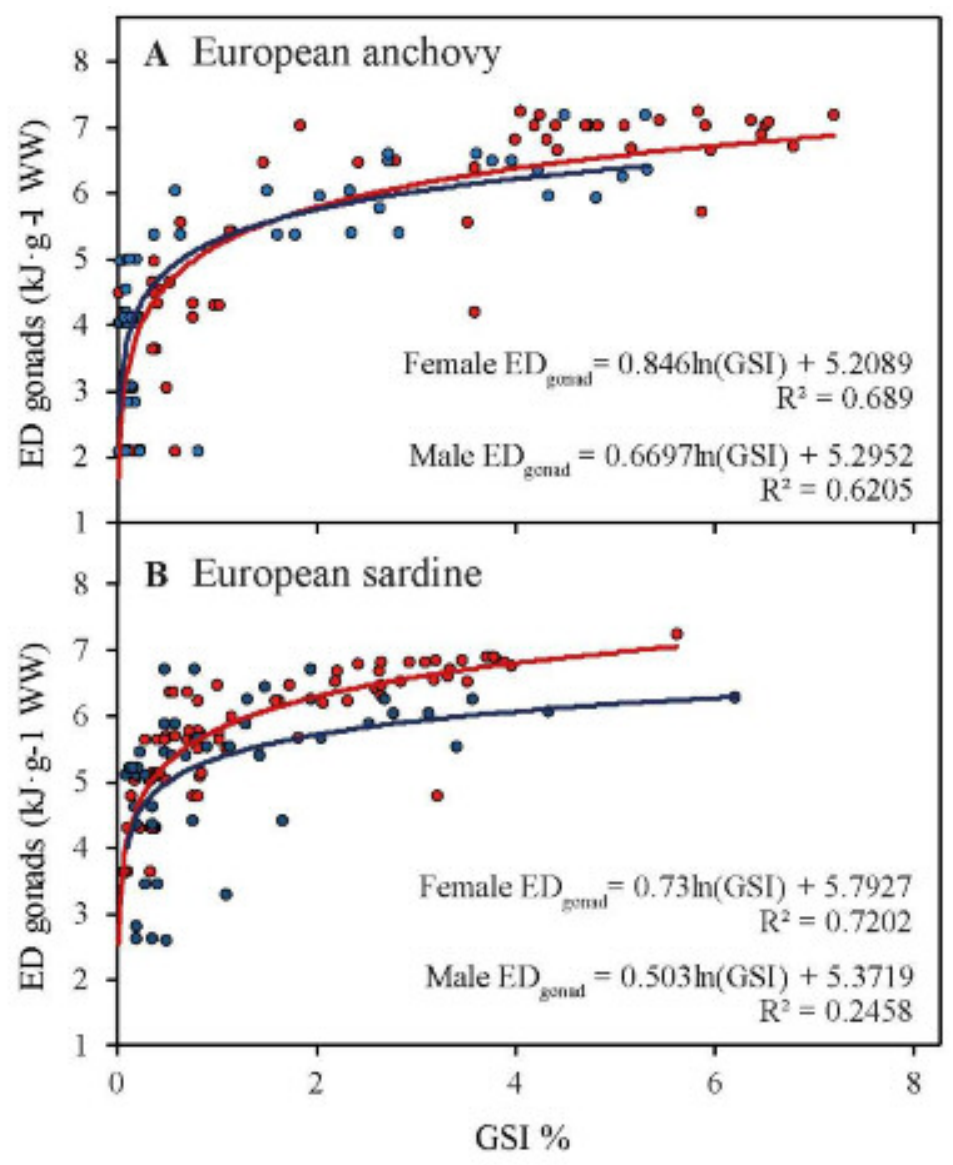

402

403 Figure 8. Relationship between the gonadosomatic index (GSI \%) and energy density 404 of gonads (ED gonads; $\mathrm{KJg}^{-1}$ wet weight), for anchovy (A) and sardine (B). Females are 405 represented in red and males in blue. Equation and logarithmic regression lines are 406 represented when the spearman correlations are statistical significant $(\mathrm{p}<0.05)$.

\section{Discussion}

\subsection{Annual body condition and energetic changes of anchovy and sardine}

Anchovy presented inter- and intra-annual variability in the relative body condition index $(\mathrm{Kn})$. In both years analysed, Kn showed higher values in spring, mainly after the peak in Chl-a and in synchrony with the increase in GSI. However, the absence of correlation observed between Chl-a and $\mathrm{Kn}$ in anchovy could be a consequence of the 
temporal lag of phytoplankton-zooplankton phenology succession. The higher values of

$414 \mathrm{Kn}$ at the beginning of spring were in accordance with the higher lipid content and ED

415 values observed for anchovy in spring in the present study. These results seem to

416 indicate that anchovy relied in large part on current food intake for reproduction.

417 Therefore, as described in previous studies, anchovy mainly exhibited an income

418 breeder strategy (Brosset et al., 2017; McBride et al., 2015).

419 Anchovy ED, lipid content and Kn showed the lowest values after the spawning season, suggesting that the final balance between energy intake and reproductive costs was negative and led to a deterioration of anchovy body condition. We observed a depletion in lipid content as early as summer before the end of reproduction activity, whereas the decline in ED showed a progressive change with minimum values after the reproduction period. Taking into account that lipids were measured in the muscle and ED in the entire individual, these results suggest that lipids in muscle were the first source of energy to be mobilized for the development of gonads in spring. In previous studies conducted in the Mediterranean Sea (in the Gulf of Lions and the Strait of Sicily), body condition of small pelagic fish was positively related to river run-off, $\mathrm{Chl}-\mathrm{a}$, and diatoms and meso-zooplankton concentrations (Basilone et al., 2006; Brosset et al., 2015b). Basilone et al. (2006) noted that the energy gained and stored before the spawning period could affect the reproductive output of anchovy in the Strait of Sicily. Therefore, the low lipid content and ED observed in our study at the end of the reproduction period could reflect unfavourable environmental conditions during the reproduction period in the spawning season of 2012 and 2013. Although in our study it is not possible to determine if the observed pattern is year-specific or is representative 
condition observed in anchovy in the last decade in the Mediterranean Sea (Albo-

438 Puigserver et al., 2019; Brosset et al., 2017; Van Beveren et al., 2014).

439 On the contrary, all condition indexes (Kn, ED, lipid) measured in sardine had a highly

440 marked seasonality, with inverse patterns between Kn and GSI. The sardine spawning

441 season covered the colder months of the year, peaking between December and February,

442 as already described in previous studies (Palomera, 1992; Palomera et al., 2007;

443 Palomera and Olivar, 1996). During the reproduction period, Kn, ED and lipids were at

444 their lowest values. Rapidly after the end of the reproduction period, coinciding with the

445 spring increase in zooplankton enhanced by strong riverine nutrient input at the Ebro

446 Delta continental shelf (Lloret et al., 2004; Salat et al., 2002), a strong increase in Kn,

447 ED and lipids was observed for sardine. Similar to previous studies (Brosset et al.,

448 2015a; Ganias et al., 2007; Nunes et al., 2011), sardine accumulated energy during the

449 resting period and seemed to supply reproduction costs with stored resources,

450 presenting a clear capital breeding strategy.

451 Nevertheless, Kn in sardine peaked in June, but was not maintained at high levels until

452 the reproduction period, as would be expected in a capital breeder (McBride et al.,

453 2015). In August 2013, Kn was under one while reproductive activity started in October

454 (GSI). In contrast, previous studies of body condition found, that Kn was maintained at

455 a high level until an increase in GSI due to the mobilization of fat reserves for the

456 development of gonads (Brosset et al., 2015b; Ganias et al., 2007; Nunes et al., 2011).

457 Thus, as in the hypothesis proposed for anchovy, the decrease in $\mathrm{Kn}$ in sardine before

458 the reproduction period could also be related to unfavourable environmental conditions

459 preventing an accumulation of sufficient energy reserves during spring and summer.

460 Similar patterns of a decline in condition at the end of summer were described for

461 sardine in the Gulf of Lions, and this was attributed to a change in phenology of primary 
and secondary production (Brosset et al., 2015b). The low energy reserves observed at the beginning of the reproduction period could suggest that sardine may also rely on direct food intake towards the end of the reproduction period. Therefore, sardine would be able to deploy both capital and income breeder strategies as was previously suggested for sardine in the eastern Mediterranean (Ganias, 2009) and Atlantic (Garrido et al., 2007). Also, the low levels of fat reserves that the sardine accumulated prior to the spawning season during our study years could have had an important effect on the quantity or quality of eggs produced during the spawning season, as was demonstrated for the Iberian sardine in Portugal (Garrido et al., 2007). In both species, $\mathrm{ED}_{\text {gonads }}$ was high for males and females during reproductively active stages with high GSI values, when female oocytes are hydrated and males produce sperm, highlighting the high energetic investment required by reproduction activity in both sexes and similar (Garrido et al., 2008; Wang and Houde, 1994). Short-lived species, could prioritize energy investment in reproduction instead of growth and maintenance, as it has been suggested for sardine and anchovy in the Gulf of Lions (Brosset et al., 2016). Therefore, assessment of GSI and energy invested in gonads is key to understand the changes in life history traits. Changes in GSI and ED with size in anchovy and sardine have been also described. In the Bay of Biscay, a dome shaped relationship in ED with size was found (Gatti et al. 2018). Although, not evaluated here size could be an important factor to include in future studies, particularly in light of the decline in the body condition of sardine and anchovy in the Mediterranean (Albo-Puigserver et al., 2019; Brosset et al., 2017; Van Beveren et al., 2014), and the importance of large females to replenish fish populations (Berneche et al. 2018).

\subsection{Indirect and direct condition indices in small pelagic fish}


In sardine, both direct methods (\% lipid and ED) were highly correlated to the indirect method $\mathrm{Kn}$, and all of them successfully captured the variability in energy reserves between the reproduction and the resting period of sardine (spring-summer and fallwinter, respectively). In anchovy, ED was better correlated to Kn, than \% lipid, suggesting that ED and Kn better captured changes in body condition than lipid content. However, we expected a better correlation between $\mathrm{Kn}$ and lipid content in the muscle as Kn was calculated from gutted individuals, whereas ED was measured in entire individuals, including mesenteric fat and gonads. Therefore, these result suggest that Kn reflected other changes rather (e.g. changes in protein content) than changes in lipid content only.

The better correlation of lipid content to $\mathrm{Kn}$ in sardine is explained by the higher variability of lipids in sardine than in anchovy due to their opposite breeding strategies (Albo-Puigserver et al., 2017). Sardine accumulates a high quantity of lipids in the muscle as well as mesenteric fat during the resting period, which are used subsequently for reproduction (Albo-Puigserver et al., 2017; Brosset et al., 2015a; Pethybridge et al., 2014). On the other hand, anchovy accumulates less energy, since the energy gain is used directly for reproduction and less energy is allocated to reserves and also has smaller size at a given age that could imply less energetic requirements (AlboPuigserver et al., 2017; Gatti et al., 2018). While lipid content analysis of muscle only measures the bulk of lipids in the muscle of the individual, direct calorimetry analysis of entire individuals measures the mesenteric fat and the lipids in gonads. Moreover, also measures changes in other compounds such as proteins, which are usually mobilized when lipids are low. Thus, in fish species that do not accumulate high quantities of lipids, like anchovy, direct calorimetry analysis to obtain ED measurements could provide a more integrative measure of changes in proximate composition than lipid 
511 content analysis. These results highlight the importance of validating the indirect

512 condition indices. Similar to our results, Brosset et al., (2015) found a weak correlation

513 between lipid content and Kn of anchovy in the Gulf of Lions, potentially due to

514 changes in protein composition. In our study, we demonstrated that the morphometric

515 index Kn better reflects the seasonal changes in ED than lipid content, and Kn can be

516 used as an indirect measure of ED for both species. Similar to previous studies on other

517 fish species (Schloesser and Fabrizio, 2017), our results support that in species that store

518 high quantities of energy, such as sardine, both lipid content and direct calorimetry are

519 appropriate methods to study body condition variability.

520 In the case of the evaluation of ED in gonads, we observed high variability in ED $_{\text {gonad }}$ 521 depending on reproduction stage and sex. This was expected, because lipid content of 522 the gonad increases when the oocytes are hydrated and also the egg quality depends on

523 female lipid content (Garrido et al., 2007, Brosset et al., 2016). For this reason, the

524 correlation between the GSI and the $\mathrm{ED}_{\text {gonad }}$ was high for anchovy and sardine females

525 and males. This is the first time that the ED of gonads has been assessed in relation to

526 the GSI, and the equation provided could be used for further studies and for

527 bioenergetics models (Pethybridge et al., 2013). Yet, it is important to note that

528 calculating the energy invested in reproduction is difficult since sardine and anchovy are

529 batch spawner species, and the energy measured at a certain moment in time does not

530 correspond to the total energy that will be invested. Moreover, the energy measured in

531 gonads corresponds to energy invested in reproduction, but also in less proportion to

532 gonad structure (Kooijman, 2010). Thus, gonad ED cannot be directly used as a

533 measure of energy allocated to reproduction, but variation in the $\mathrm{ED}_{\text {gonad }}$ can be used as

534 an indirect measure of changes in energy invested in reproduction, providing a starting 
535 point in bioenergetics model parameterisation (Gatti et al., 2017; Pethybridge et al., $5362013)$.

\section{Conclusions}

539 This study highlights the importance of seasonal energetic variation in small pelagic

540 fish in understanding their population dynamics and the need to validate the methods

541 used to measure body condition. The annual body condition and energetic cycle of both

542 species were related to the temporal lag between spawning seasons and the late winter-

543 early spring phytoplankton bloom as has been described in other Mediterranean areas

544 (Basilone et al., 2006; Brosset et al., 2015b; Pethybridge et al., 2014). In line with the

545 observed energy dynamics of sardine and anchovy in the Gulf of Lions (Brosset et al.,

546 2016), the populations of the Ebro river Delta area presented low energy reserves at the

547 end of summer and beginning of fall. This could support the hypothesis related to

548 changes in the phenology of plankton, as being an important driver of these species

549 declines (Saraux et al., 2019). Therefore, a continuous monitoring of the monthly

550 variability in body condition over several years in relation to changes in environmental

551 parameters is needed to further explore this hypothesis (Albo-Puigserver et al., 2019;

552 Brosset et al., 2017). In addition, the comparison between direct and indirect condition

553 indexes revealed that ED and Kn are the preferable methods to capture seasonal

554 variability in condition for anchovy. For sardine, all direct and indirect methods

555 assessed are suitable for evaluating condition variability. Considering the likely current

556 overexploited stock status of sardine and anchovy in the northwestern Mediterranean

557 Sea (Coll et al., 2019), and the observed decline of body condition in several areas of

558 the basin in the last two decades (Brosset et al., 2017), the continuous evaluation of the

559 life history traits of small pelagic fish is needed to improve the management advice 
560

561

562

563

564

565

566

567

568

569

570

571

572

573

574

575

576

577

578

579

580

581

582

583

584

585

586

587

588

589

590

591

(Lloret et al., 2012). Our study presents important data in this direction, which can be

relevant for future comparison. Of special importance is the monitoring of the energy

reserves in critical periods (e.g. before the reproduction period) to detect if it recovers or declines in the northwestern Mediterranean Sea.

\section{Acknowledgements}

We would like to thank all of the participants of the ECOTRANS Project, fishermen and crew on board the R.V. Ángeles Alvariño. This study was funded by ECOTRANS (CTM2011-26333) and PELWEB (ES-PN-2017-CTM2017-88939-R) projects. M.A.-P. was funded by a FPI grant (BES-2012-054267, Spanish Ministry of Economy and Competitiveness). J.N was funded by a Ramon y Cajal contract (RYC-2015-17809) of the Spanish Government.

\section{Literature cited}

Albo-Puigserver, M., Giraldez, A., Hidalgo, M., Ramírez, J.G., Torres, P., Massaro, A., Sbrana, M., Bellido, J.M., Coll, M., 2019. Report on historical reproductive pattern (Size and age at first maturity and reproductive period). Evaluation of the population status and specific management alternatives for the small pelagic fish stocks in the Northwestern Mediterranean Sea (SPELMED) . Barcelona, Spain.

Albo-Puigserver, M., Muñoz, A., Navarro, J., Coll, M., Pethybridge, H., Sánchez, S., Palomera, I., 2017. Ecological energetics of forage fish from the Mediterranean Sea: Seasonal dynamics and interspecific differences. Deep. Res. Part II Top. Stud. Oceanogr. 140. https://doi.org/10.1016/j.dsr2.2017.03.002

Anderson, M., Gorley, R., Clarke, K., 2008. PERMANOVA for PRIMER: guide to software and statistical methods. PRIMER-E Ltd., Plymouth, United Kingdom.

Anthony, J. a., Roby, D.D., Turco, K.R., 2000. Lipid content and energy density of forage fishes from the northern Gulf of Alaska. J. Exp. Mar. Bio. Ecol. 248, 53-78. https://doi.org/10.1016/S0022-0981(00)00159-3

Bakun, A., 1996. Patterns in the ocean: ocean processes and marine population dynamics. California Sea Grant College System, National Oceanic and Atmospheric Administration in cooperation with Centro de Investigaciones Biológicas del Noroeste. https://doi.org/10.1016/s0278-4343(97)00037-x

Barneche, D. R., Robertson, D. R., White, C. R., Marshall, D. J. (2018). Fish 
reproductive-energy output increases disproportionately with body size. Science, 360, 642-645. https://doi.org/10.1126/science.aao6868

Basilone, G., Guisande, C., Patti, B., Mazzola, S., Cuttitta, A., Bonanno, A., Vergara, A.R., Maneiro, I., 2006. Effect of habitat conditions on reproduction of the European anchovy (Engraulis encrasicolus) in the Strait of Sicily. Fish. Oceanogr. 15, 271-280. https://doi.org/10.1111/j.1365-2419.2005.00391.x

Black, D., Love, R.M., 1986. The sequential mobilisation and restoration of energy reserves in tissues of Atlantic cod during starvation and refeeding. J. Comp. Physiol. B 156, 469-479. https://doi.org/10.1007/BF00691032

Brosset, P., Fromentin, J.-M., Ménard, F., Pernet, F., Bourdeix, J.-H., Bigot, J.L., Van Beveren, E., Pérez Roda, M.A., Choy, S., Saraux, C., 2015a. Measurement and analysis of small pelagic fish condition: A suitable method for rapid evaluation in the field. J. Exp. Mar. Bio. Ecol. 462, 90-97. https://doi.org/10.1016/j.jembe.2014.10.016

Brosset, P., Fromentin, J.M., Van Beveren, E., Lloret, J., Marques, V., Basilone, G., Bonanno, A., Carpi, P., Donato, F., Čikeš Keč, V., De Felice, A., Ferreri, R., Gašparević, D., Giráldez, A., Gücü, A., Iglesias, M., Leonori, I., Palomera, I., Somarakis, S., Tičina, V., Torres, P., Ventero, A., Zorica, B., Ménard, F., Saraux, C., 2017. Spatio-temporal patterns and environmental controls of small pelagic fish body condition from contrasted Mediterranean areas. Prog. Oceanogr. 151, 149162. https://doi.org/10.1016/j.pocean.2016.12.002

Brosset, P., Lloret, J., Munoz, M., Fauvel, C., Van Beveren, E., Marques, V., Fromentin, J.-M., Ménard, F., Saraux, C., 2016. Body reserves mediate trade-offs between life-history traits: new insights from small pelagic fish reproduction. $\mathrm{R}$. Soc. Open Sci. 3. 160202. http://dx.doi.org/10.1098/rsos.160202

Brosset, P., Ménard, F., Fromentin, J., Bonhommeau, S., Ulses, C., Bourdeix, J., Bigot, J., Van Beveren, E., Roos, D., Saraux, C., 2015b. Influence of environmental variability and age on the body condition of small pelagic fish in the Gulf of Lions. Mar. Ecol. Prog. Ser. 529, 219-231. https://doi.org/10.3354/meps11275

Clarke, K., Gorley, R., 2006. PRIMER v6: user manual/tutorial. PRIMER-E, Plymouth, United Kingdom.

Coll, M., Albo-Puigserver, M., Navarro, J., Palomera, I., Dambacher, J.M., 2019. Who is to blame? Plausible pressures on small pelagic fish population changes in the northwestern Mediterranean Sea. Mar. Ecol. Prog. Ser. 617-618, 277-294. https://doi.org/10.3354/meps 12591

Cury, P., Bakun, A., Crawford, R.J.M., Jarre, A., Quiñones, R.A., Shannon, L.J., Verheye, H.M., 2000. Small pelagics in upwelling systems: patterns of interaction and structural changes in "wasp-waist" ecosystems. ICES J. Mar. Sci. 57, 603-618. https://doi.org/10.1006/jmsc.2000.0712

Cury, P.M., Boyd, I.L., Bonhommeau, S., Anker-Nilssen, T., Crawford, R.J.M., Furness, R.W., Mills, J.A., Murphy, E.J., Osterblom, H., Paleczny, M., Piatt, J.F., Roux, J.-P., Shannon, L., Sydeman, W.J., 2011. Global Seabird Response to Forage Fish Depletion--One-Third for the Birds. Science (80-. ). 334, 1703-1706. https://doi.org/10.1126/science.1212928 
Drent, R.H., Daan, S., 1980. The Prudent Parent: Energetic Adjustments in Avian Breeding. Ardea 55, 225-252. https://doi.org/10.5253/arde.v68.p225

Dubreuil, J., Petitgas, P., 2009. Energy density of anchovy Engraulis encrasicolus in the Bay of Biscay. J. Fish Biol. 74, 521-534. https://doi.org/10.1111/j.10958649.2008.02143.x

FAO, 2018. FAO yearbook. Fisheries and Aquaculture Statistics 2016, Fao. Rome. https://doi.org/10.5860/CHOICE.50-5350

Ferrer-Maza, D., Lloret, J., Faliex, E., Sasal, P., 2016. Links between parasitism , energy reserves and fecundity of European anchovy, Engraulis encrasicolus, in the northwestern Mediterranean Sea. Conserv. Physiol. 4, 1-13. https://doi.org/10.1093/conphys/cov069.Introduction

Folch, J., Lees, M., Sloane Stanley, G.H., 1957. A simple method for the isolation and purification of total lipides from animal tissues. J. Biol. Chem. 226, 497-509.

Ganias, K., 2009. Linking sardine spawning dynamics to environmental variability. Estuar. Coast. Shelf Sci. 84, 402-408. https://doi.org/10.1016/j.ecss.2009.07.004

Ganias, K., Somarakis, S., Koutsikopoulos, C., Machias, A., 2007. Factors affecting the spawning period of sardine in two highly oligotrophic Seas. Mar. Biol. 151, 15591569. https://doi.org/10.1007/s00227-006-0601-0

Garrido, S., Rosa, R., Ben-Hamadou, R., Cunha, M.E., Chícharo, M.A., van der Lingen, C.D., 2007. Effect of maternal fat reserves on the fatty acid composition of sardine (Sardina pilchardus) oocytes. Comp. Biochem. Physiol. B. Biochem. Mol. Biol. 148, 398-409. https://doi.org/10.1016/j.cbpb.2007.07.008

Garrido, S., Rosa, R., Ben-Hamadou, R., Cunha, M.E., Chícharo, M.A., van der Lingen C.D., 2008. Spatio-temporal variability in fatty acid trophic biomarkers in stomach contents and muscle of Iberian sardine (Sardina pilchardus) and its relationship with spawning. Mar Biol 154: 1053-1065. https://doi.org/10.1007/s00227-0080999-7

Gatti, P., Cominassi, L., Duhamel, E., Grellier, P., Le Delliou, H., Le Mestre, S., Rabiller, M., Spitz, J., Huret, M., 2018. Bioenergetic condition of anchovy and sardine in the Bay of Biscay and English Channel. Prog. Oceanogr. 166, 129-138. https://doi.org/10.1016/J.POCEAN.2017.12.006

Gatti, P., Petitgas, P., Huret, M., 2017. Comparing biological traits of anchovy and sardine in the Bay of Biscay: A modelling approach with the Dynamic Energy Budget. Ecol. Modell. 348, 93-109. https://doi.org/10.1016/J.ECOLMODEL.2016.12.018

Giannoulaki, M., Schismenou, E., Pyrounaki, M.-M., 2014. Habitat Characterization and Migrations, in: Biology and Ecology of Sardines and Anchovies. CRC Press, pp. 285-307. https://doi.org/10.1201/b16682-11

Giorgi, F., 2006. Climate change hot-spots. Geophys. Res. Lett. 33, L08707. https://doi.org/10.1029/2006GL025734

Hoegh-Guldberg, O., Jacob, D., Taylor, M., Bindi, M., Brown, S., Camilloni, A., Diedhiou, A., Djalante, R., Ebi, K.L., Engelbrecht, F., Guiot, J., Hijioka, Y., Mehrotra, S., Payne, A., S.I., S., Thomas, A., Warren, R., Zhou, G., 2018. Impacts 
of $1.5^{\circ} \mathrm{C}$ of Global Warming on Natural and Human Systems, in: Global Warming of $1.5^{\circ} \mathrm{C}$. An IPCC Special Report on the Impacts of Global Warming of $1.5^{\circ} \mathrm{C}$ above Pre-Industrial Levels and Related Global Greenhouse Gas Emission Pathways, in the Context of Strengthening the Global Response to the Threat of Climate Change,. pp. 175-311.

ICES, 2008. Report of the Workshop on Small Pelagics (Sardina pilchardus, Engraulis encrasicolus) maturity stages (WKSPMAT), 10-14 November 2008, Mazara del Vallo, Italy.

Kooijman, S.A.L.M., 2010. Dynamic Energy Budgets Theory for Metabolic Organization, 3rd editio. ed. Cambridge University Press, Great Britain.

Le Cren, E.D., 1951. The Length-Weight Relationship and Seasonal Cycle in Gonad Weight and Condition in the Perch (Perca fluviatilis). J. Anim. Ecol. 20, 201. https://doi.org/10.2307/1540

Lloret, J., Lleonart, J., Solé, I., Fromentin, J.-M., 2001. Fluctuations of landings and environment conditios in the north-western Mediterranean Sea. Fish. Oceanogr. 10, 33-50. https://doi.org/10.1046/j.1365-2419.2001.00151.x

Lloret, J., Palomera, I., Salat, J., Solé, I., 2004. Impact of freshwater input and wind on landings of anchovy (Engraulis encrasicolus) and sardine (Sardina pilchardus) in shelf waters surrounding the Ebre (Ebro) River delta (north-western Mediterranean). Fish. Oceanogr. 13, 102-110.

Lloret, J., Faliex, E., Shulman, G.E., Raga, J.-A., Sasal, P., Muñoz, M., Casadevall, A.E., Ahuir-Baraja, A.E., Montero, F.E., Repullés-Albelda, A., Cardinale, M., Rätz H.-J., Vola, S., Ferrer, D., 2012. Fish Health and Fisheries, Implications for Stock Assessment and Management: The Mediterranean Example, Reviews in Fish Sci, 20:3, 165-180. http://dx.doi.org/10.1080/10641262.2012.695817

Lloret, J., Shulman, G., Love, R.M., 2013. Condition and Health Indicators of Exploited Marine Fishes, Condition and Health Indicators of Exploited Marine Fishes. John Wiley \& Sons, Oxford. https://doi.org/10.1002/9781118752777

McBride, R.S., Somarakis, S., Fitzhugh, G.R., Albert, A., Yaragina, N.A., Wuenschel, M.J., Alonso-Fernández, A., Basilone, G., 2015. Energy acquisition and allocation to egg production in relation to fish reproductive strategies. Fish Fish. 16, 23-57. https://doi.org/10.1111/faf.12043

McPherson, L.R., Slotte, A., Kvamme, C., Meier, S., Marshall, C.T., 2011. Inconsistencies in measurement of fish condition: a comparison of four indices of fat reserves for Atlantic herring (Clupea harengus). ICES J. Mar. Sci. 68, 52-60. https://doi.org/10.1093/icesjms/fsq148

Melin, F., 2013. EMIS - PATHFINDER Monthly climatology sea surface temperature $(4 \mathrm{~km})$ in degree-C. European Commission, Joint Research Centre (JRC) [Dataset] PID: http://data.europa.eu/89h/5838224e-174e-4172-8035-b6c17f07748b

Millán, M., 1999. Reproductive characteristics and condition status of anchovy Engraulis encrasicolus L. from the Bay of Cadiz (SW Spain). Fish. Res. 41, 7386. https://doi.org/10.1016/S0165-7836(99)00010-7

Mustać, B., Sinovčić, G., 2009. Comparison of mesenteric and tissue fat content in 
relation to sexual cycle of the sardine, Sardina pilchardus (Walb., 1792), in the eastern Middle Adriatic fishery grounds (Croatia). J. Appl. Ichthyol. 25, 595-599. https://doi.org/10.1111/j.1439-0426.2009.01285.x

Nunes, C., Silva, A., Soares, E., Ganias, K., 2011. The use of hepatic and somatic indices and histological information to characterize the reproductive dynamics of Atlantic sardine sardina pilchardus from the Portuguese coast. Mar. Coast. Fish. 3, 127-144. https://doi.org/10.1080/19425120.2011.556911

Oliver, E.C.J., Donat, M.G., Burrows, M.T., Moore, P.J., Smale, D.A., Alexander, L. V., Benthuysen, J.A., Feng, M., Sen Gupta, A., Hobday, A.J., Holbrook, N.J., Perkins-Kirkpatrick, S.E., Scannell, H.A., Straub, S.C., Wernberg, T., 2018. Longer and more frequent marine heatwaves over the past century. Nat. Commun. 9, 1324. https://doi.org/10.1038/s41467-018-03732-9

Palomera, I., 1992. Spawning of anchovy Engraulis encrasicolus in the northwestern Mediterranean relative to hydrographic features in the region. Mar. Ecol. Prog. Ser. 79, 215-223. https://doi.org/10.3354/meps079215

Palomera, I., Olivar, M.P., 1996. Nearshore ichthyoplankton off the Costa Brava (Northwest Mediterranean). Publ. Espec. Inst. Esp. Ocean. 22, 71-75.

Palomera, I., Olivar, M.P., Salat, J., Sabatés, a., Coll, M., García, a., Morales-Nin, B., 2007. Small pelagic fish in the NW Mediterranean Sea: An ecological review. Prog. Oceanogr. 74, 377-396. https://doi.org/10.1016/j.pocean.2007.04.012

Pethybridge, H., Bodin, N., Arsenault-Pernet, E.J., Bourdeix, J.H., Brisset, B., Bigot, J.L., Roos, D., Peter, M., 2014. Temporal and inter-specific variations in forage fish feeding conditions in the NW Mediterranean: lipid content and fatty acid compositional changes. Mar. Ecol. Prog. Ser. 512, 39-54. https://doi.org/10.3354/meps 10864

Pethybridge, H., Roos, D., Loizeau, V., Pecquerie, L., Bacher, C., 2013. Responses of European anchovy vital rates and population growth to environmental fluctuations: An individual-based modeling approach. Ecol. Modell. 250, 370-383. https://doi.org/10.1016/j.ecolmodel.2012.11.017

Piroddi, C., Coll, M., Liquete, C., Macias, D., Greer, K., Buszowski, J., Steenbeek, J., Danovaro, R., Christensen, V., 2017. Historical changes of the Mediterranean Sea ecosystem: modelling the role and impact of primary productivity and fisheries changes over time. Sci. Rep. 7, 44491. https://doi.org/10.1038/srep44491

Quattrocchi, F., Maynou, F., 2017. Environmental drivers of sardine (Sardina pilchardus) in the Catalan Sea (NW Mediterranean Sea). Mar. Biol. Res. 13, 10031014. https://doi.org/10.1080/17451000.2017.1331039

R Development Core Team, 2018. R: a language and environment for statistical computing. R Found. Stat. Comput. Vienna, Austria 3-900051-07-0.

Rosa, R., Gonzalez, L., Broitman, B., Garrido, S., Santos, A., Nunes, M., 2010. Bioenergetics of small pelagic fishes in upwelling systems: relationship between fish condition, coastal ecosystem dynamics and fisheries. Mar. Ecol. Prog. Ser. 410, 205-218. https://doi.org/10.3354/meps08635

Sabatés, A., Olivar, M.P., Salat, J., Palomera, I., Alemany, F., 2007. Physical and 
biological processes controlling the distribution of fish larvae in the NW Mediterranean. Prog. Oceanogr. 74, 355-376. https://doi.org/10.1016/J.POCEAN.2007.04.017

Salat, J., 1996. Review of hydrographic environmental factors that may influence anchovy habitats in northwestern Mediterranean. Sci. Mar. 60, 21-32.

Salat, J., Garcia, M. a., Cruzado, A., Palanques, A., Arín, L., Gomis, D., Guillén, J., De León, A., Puigdefàbregas, J., Sospedra, J., Velásquez, Z.R., 2002. Seasonal changes of water mass structure and shelf slope exchanges at the Ebro shelf (NW Mediterranean). Cont. Shelf Res. 22, 327-348. https://doi.org/10.1016/S02784343(01)00031-0

Saraux, C., Van Beveren, E., Brosset, P., Queiros, Q., Bourdeix, J.-H., Dutto, G., Gasset, E., Jac, C., Bonhommeau, S., Fromentin, J.-M., 2019. Small pelagic fish dynamics: A review of mechanisms in the Gulf of Lions. Deep Sea Res. Part II Top. Stud. Oceanogr. 159, 52-61. https://doi.org/10.1016/J.DSR2.2018.02.010

Schloesser, R.W., Fabrizio, M.C., 2017. Condition Indices as Surrogates of Energy Density and Lipid Content in Juveniles of Three Fish Species. Trans. Am. Fish. Soc. 146, 1058-1069. https://doi.org/10.1080/00028487.2017.1324523

Shulman, G.E., Love, R.M., 1999. The biochemical ecology of marine fishes. Advances in marine biology. Volume 36,. Academic Press.

Somarakis, S., 2005. Marked interannual differences in reproductive parameters and daily egg production of anchovy in the northern Aegean Sea. Belgian J. Zool. 135, 247-252.

Somarakis, S., Ganias, K., Tserpes, G., Koutsikopoulos, C., 2004. Ovarian allometry and the use of the gonosomatic index: A case study in the Mediterranean sardine, Sardina pilchardus. Mar. Biol. 146, 181-189. https://doi.org/10.1007/s00227-0041419-2

Stearns, S.C., 1989. The Evolutionary Significance of Phenotypic Plasticity. Bioscience 39, 436-445. https://doi.org/10.2307/1311135

Sutton, S.G., 2011. Relationship among fat weight, body weight, water weight, and condition factors in wild Atlantic salmon Parr. Trans. Am. Fish. Soc.129, 527538. https://doi.org/10.1577/1548-8659(2000)129<0527:RAFWBW >2.0.CO;2

Tirelli, V., Borme, D., Tulli, F., Cigar, M., Fonda Umani, S., Brandt, S.B., 2006. Energy density of anchovy Engraulis encrasicolus L. in the Adriatic Sea. J. Fish Biol. 982-989. https://doi.org/10.1111/j.1095-8649.2005.00987.x

Tocher, D.R., 2003. Metabolism and Functions of Lipids and Fatty Acids in Teleost Fish. Rev. Fish. Sci. 11, 107-184. https://doi.org/10.1080/713610925

Tugores, P., Giannoulaki, M., Iglesias, M., Bonanno, A., Tičina, V., Leonori, I., MacHias, A., Tsagarakis, K., Díaz, N., Giráldez, A., Patti, B., De Felice, A., Basilone, G., Valavanis, V., 2011. Habitat suitability modelling for sardine Sardina pilchardus in a highly diverse ecosystem: The Mediterranean Sea. Mar. Ecol. Prog. Ser. 443, 181-205. https://doi.org/10.3354/meps09366

Van Beveren, E., Bonhommeau, S., Fromentin, J.-M., Bigot, J.-L., Bourdeix, J.-H., Brosset, P., Roos, D., Saraux, C., 2014. Rapid changes in growth, condition, size 
and age of small pelagic fish in the Mediterranean. Mar. Biol. 161, 1809-1822. https://doi.org/10.1007/s00227-014-2463-1

Wang, S.B., Houde, E.D., 1994. Energy storage and dynamics in bay anchovy Anchoa mitchilli. Mar. Biol. 121, 219-227. https://doi.org/10.1007/BF00346729 